\title{
The Binding Prediction of 6-Paradol and its Derivatives on TRPV1 Agonist as a New Compound for Treating Painful Diabetic Neuropathy
}

\author{
Finas Rahmayanti ${ }^{1}$, Dwi Koko Pratoko ${ }^{2}$, Fifteen Aprila Fajrin ${ }^{3 *}$ \\ ${ }^{1}$ Undergraduate student, Faculty of Pharmacy, University of Jember, Indonesia \\ ${ }^{2}$ Chemistry Pharmacy, Faculty of Pharmacy, University of Jember, Indonesia \\ ${ }^{3}$ Clinical and Community Pharmacy, Faculty of Pharmacy, University of Jember, Indonesia \\ "E-mail: fifteen.farmasi@unej.ac.id
}

\begin{abstract}
Ginger was reported to have a suppressive effect on pain in patients with Painful Diabetic Neuropathy (PDN). Our latest study revealed that 6-shogaol, one of the ginger components, had the best affinity in the Transient Receptor Potential Vanilloid 1 (TRPV1), a key receptor in PDN). Paradol, which obtained from gingerol and shogaol metabolism, also had potent activities in several diseases, compared to the other derivatives of gingerol and shogaol. However, shogaol and paradol is very similar in chemical structure with only different in one double bond in 4-5 position. Until now there is no explanation about paradol mechanism in TRPV1. Based on this, our study was designed to predict the activity of 6-paradol and its derivatives to TRPV1 as target receptor in PDN using in-silico model. 2-paradol, 4-paradol, 6-paradol, 8-paradol and 10-paradol were used as ligands. Capsaisin, the agonist of TRPV1, was used as a native ligand in this study. TRPV1 was obtained from protein data bank (PDB). Ligand bond prediction and affinity was performed using Molegro Virtual Docker. The results showed 2-paradol, 4-paradol, 6-paradol, 8-paradol and 10paradol had good affinity against TRPV1. These result indicated that 6-paradol and the derivatives had potential as a drug compound for PDN therapy.
\end{abstract}

Keywords: ginger, 6-paradol, painful diabetic neuropathy, trpv1.

\section{INTRODUCTION}

Ginger is one of plants, which regulates central nervous system (CNS) disorder by modulating inflammatory pathways (Gaire et al., 2015). Previous report investigated that ginger juice had analgesic effect in hot plate-induced pain in rats (Mantiri et al, 2013). Main compound, which is believed responsible for this activity in ginger, were gingerol, shogaol and paradol (Black et al., 2010, Ali et al., 2008). Another finding, gingerol, shogaol, zingerone, diarylheptanoids and its derivatives especially paradol worked through cyclooxygenase inhibition and caused the decreasing of prostaglandin synthesis, then reduced pain (Black et al., 2010, Ali et al., 2008, Haghighi et al., 2005, Mantiri et al, 2013). 8-Paradol also known has an ability to inhibit platelet aggregation and potential as inhibitor of cyclooxygenase-1 agent (NurtjahjaTjendraputra et al., 2003).

Painful diabetic neuropathy (PDN) is a complex chronic disorder, related to abnormality of nervous system in patients with diabetic. Higher incidence in PDN is depends on aging and also duration of diabetes mellitus (Hutapea et al, 2016). Many agents are involved in pathophysiology of PDN such as glucose metabolism flux through the polyol pathway; the hexosamine pathway; excess or inappropriate activation of protein kinase $\mathrm{C}$ (PKC) isoforms; and accumulation of advanced glycation end products (AGEs) (Smith \& Argoff, 2013). It is important to treat PDN because its complex pathophysiology and impact into patient's quality of life.

Non-steroidanti-inflammatory drugs (NSAIDs) and opioid analgesic were reported fail to overcome pain in PDN. The other agents such as antidepressant also did not effective and had a high side effect effect (Wahyuliati, 2006). That's why it is challenging to find a new substance to treat PDN. One of the target drugs to treat PDN is the transient receptor protein vanilloid-1 (TRPV1).

TRPV1 is a non-selective cation channel which is permeable to $\mathrm{Ca}^{2+}$. In our body, TRPV1 is expressed in peripheral sensory nerves and essential for certain modalities of pain sensation and for tissue injury-induce thermal hyperalgesia (Kano et al., 2009). Insulin deficiency causes down regulation of TRPV1 expression, which is related into hyperalgesia and hypoalgesia (Pabbidi et al., 2008). TRPV1 can be blocked using its agonist via desensitization mechanism and antagonist receptor (Suri \& Szallasi, 2008). Desensitization action via agonist significantly 
decreasing the fasting plasma insulin levels, improving glucose tolerance via enhancement of insulin secretion and increased glucose infusion rate during due glycemic hyperinsulinemic clamp versus vehicle controls (Gram et al., 2005). Capsaicin, one of the compounds in plants, which had been already studied as agonist TRPV1 and used as PDN treatment. Capsaicin used in topical form for PDN patient because of the limitation according to side effect in gastrointestinal of capsaicin when it is used orally. Based on (Suri \& Szallasi, 2008) capsaicin bound selectively and reversible to TRPV1.

6-paradol, an TRPV1 agonist same as capsaicin, was found as minor component in ginger, but known more effective than 6shogaol from in vitro and in vivo study. 6paradol has been recognized as a bioactive species, and it has been investigated for various biological or pharmacological activities, such as neuroprotective effects, anti-obesity effects (Wei et al., 2017), tumor suppressing effects, chemopreventive properties (Keum et al., 2002), antioxidant effects, and COX1 inhibitor (Nurtjahja-Tjendraputra et al., 2003). This compound was a metabolite from 6-shogaol which is come from reduction reaction (Jo et al., 2016, Wei et al., 2017). That's why 6paradol directly administration is suggested more effective and faster to treat PDN.

There is no information regarding the activity of 6-paradol and another paradol derivates in TRPV1. So, our study was aimed to investigate and predict the binding of 6paradol and its derivates in TRPV1 using insilico method. This result is important to find new substances in PDN therapy with the same activity as capsaicin but give lower side effect as well.

\section{MATERIAL AND METHOD}

\section{Software and hardware}

Molecular docking was analyzed using Notebook brand Asus E203NAH with processor Intel(R) Celeron(R) CPU N3350@1.10GHz and Molegro Virtual Docker 2013.6.0.1 as the software for docking. TRPV1 protein and the native ligand (4DY) were extracted from Protein Data Bank (PDB) with code $2 \mathrm{~N} 27$. The $2 \mathrm{~N} 27$ was consisted byprotein structure, native ligand (4DY, capsaicin) and cofactors. The structure of 6-paradol and derivatives were created with ChemDraw Professional 15.1. then minimized the energy using Chem3D 15.1. and saved as Sybil2/Mol2 files.

\section{Compounds preparation}

The structures of Capsaicin, 6-paradol and its derivatives were drawn used ChemDraw Professional 15.1 to get 2D molecule structures. Optimization of the geometrical isomeric structure of all compounds were done by minimizing energy (MM2) using Chem3D 15.1 and then saved as Mol2.

\section{Cavity preparation}

Cavities were detected using software Molegro Virtual Docker by import 2N27.pdb file. Cavity was chosen based on the presence of native ligands attached to the cavity that had been formed.

\section{Validation}

Validation was determined by docking native ligands and capsaicin compounds to the selected cavity. There were 20 models of native ligand then was chosen based on who has the smallest RMSD. RMSDS showed the similarity or compatibility between the compound that was docked with the selected cavity. The native ligand (4DY) capsaicin was validated with three times replications.

Molecular docking of 6-paradol and its derivatives

PDB protein file and other compounds with Mol2 format then were imported into Molegro Virtual Docker. The 6-paradol and its derivatives were docked with the general settings with three times validation. The result was shown as rerank score, root mean square deviation (RMSD) score, and also hydrogen bond. The affinity ability was described using rerank score which defined the energy to bind the protein or receptor as target.

\section{Hydrogen bonds}

Hydrogen bonds and steric interactions were obtained through the imported docking result using Molegro Virtual Docker 2013.6.0.1 as the software for docking.

\section{Physicochemical parameters}

The physicochemical parameters were taken from the ChemDraw Professional 15.1 software. We got the information about chemical properties such as $\log \mathrm{P}$ and MR value using import two-dimension structure of each compound.

\section{Data Analysis}

All data are expressed as mean \pm S.E.M. Data analysis was processed through IBM SPSS Statistics 22 software using one-way-ANOVA test. Data were considered significant when $\mathrm{p}$ values $\leq 0.05$.

\section{RESULTS AND DISCUSSION}

The docking method is used to determine the binding ability between the structure of the 6paradol and its derivatives with TRPV1 as the pain receptor target. In this research, we can not get RMSD value $\leq 2$ after validating 4TRPV1 code using PDB i.e. 2N27, 3J5R, 5IRZ and 3J9J. The TRPV1 code 3J9J did not 
include native ligand and capsaicin as native ligand in code 5IRZ did not find inside the cavity, that's why both of them were excluded for further test. After validating, we found that the smallest RMSD was shown using TRPV1 (2N27), with RMSD value 6.78792. Then, we chose this ligand to compare the affinity between 6 paradol and its derivates using capsaicin as native ligand. This result did not describe the ideal situation for validation, and this might be the limitation of our study.

Our result showed capsaicin in cavity 1 that had the smallest RMSD then reanalyzed three times, as seen in Table 1. Hydrogen bonds were seen in Fig. 1.

Table 1 . Validation of capsaicin with cavity 1

\begin{tabular}{cccc}
\hline \multirow{2}{*}{ Replications } & \multicolumn{3}{c}{ Capsaicin } \\
\cline { 2 - 4 } & $\begin{array}{c}\text { Rerank } \\
\text { Score }\end{array}$ & RMSD & $\begin{array}{c}\text { MolDock } \\
\text { Score }\end{array}$ \\
\hline 1 & -1362.55 & 6.78792 & -1835.49 \\
2 & -1365.2 & 11.8887 & -1790.89 \\
3 & -1368.42 & 7.80868 & -1928.16 \\
\hline
\end{tabular}

Molecular Docking analyzed using cavity 1 as the best cavity which had been validated with native ligand. The docking of each compounds were tested in three replications.

Docking was evaluated by positioning all compounds in the same place with the results of validation. Molecular docking results with Molegro Virtual Docker in the form of pose assessment functions such as DockSore, HBond, RMSD and Rerank Score (Puspaningtyas et al., 2012). Rerank score indicates the energy needed for a compound to bind to the receptor so that the smaller rerank score means that the energy needs to bind into the receptor is also smaller. The binding energy is related to the affinity value of ligand bonds with receptors (Fajrin et al., 2018). Affinity can be determined as tendency of a compound to form chemical bonds with other elements or compounds. Smaller rerank score means that it had the higher affinity. Based on one way ANOVA test, capsaicin has significantly different with 2-paradol, see at table 2. But 2paradol has the biggest rerank score value that means it has the lowest affinity to the TRPV1.

The physicochemical parameter values used include lipophility properties in the form of partition coefficient ( $\log \mathrm{P})$ values and structural disabilities based on the molar refractivity values (MR) shown in the table 3 . Lipophility is the ability of compounds to be able to pass through cell membranes, while the structural friction of the test compounds will increase the likelihood of good interactions on the target side of the active enzyme. The results show that 10-paradol has the highest $\log \mathrm{P}$ value and 2-paradol has the smallest $\log \mathrm{P}$ value where it wassimilar tendency with its MR value.Capsaicin as native ligand had a $\log \mathrm{P}$ between 2-paradol and 4-paradol.

Table 2. Molecular docking result of 6-paradol and its derivatives

\begin{tabular}{ccccc}
\hline \multirow{2}{*}{ Ligand } & \multicolumn{3}{c}{ Rerank Score } & \multirow{2}{*}{ Mean \pm SEM } \\
\cline { 2 - 4 } & 1 & 2 & 3 & \\
\hline Capsaicin & -1362.55 & -1365.2 & -1368.42 & $-1365.39 \pm 1.69718^{\mathrm{a}}$ \\
2-Paradol & -1181.82 & -1179.51 & -1237.69 & $-1199.67 \pm 19.02003^{\mathrm{b}}$ \\
4-Paradol & -1224.23 & -1253.01 & -1312.36 & $-1263.20 \pm 25.94611^{\mathrm{ab}}$ \\
6-Paradol & -1379.42 & -1315.43 & -1301.45 & $-1332.10 \pm 24,00171^{\mathrm{a}}$ \\
8-Paradol & -1279.9 & -1393.96 & -1313.68 & $-1329.18 \pm 33.82607^{\mathrm{a}}$ \\
10-Paradol & -1336.02 & -1268.97 & -1254.1 & $-1295.98 \pm 15.48327^{\mathrm{a}}$ \\
\hline
\end{tabular}

Note: $a$ is significantly different versus $b$

Table 3. Physicochemical parameters

\begin{tabular}{ccc}
\hline Substance & LogP & MR \\
\hline Capsaicin & 3.66 & 91.4 \\
2-Paradol & 3.02 & 63.47 \\
4-Paradol & 3.85 & 72.66 \\
6-Paradol & 4.69 & 81.86 \\
8-Paradol & 5.52 & 91.06 \\
10-Paradol & 6.35 & 100.26 \\
\hline
\end{tabular}


$\log \mathrm{P}$ value increased as the number of the carbon chain. Capsaicin has a $\log \mathrm{P}$ value of 3.66, 2-paradol has a $\log P$ value of 3.02 and 10 -paradol has the largest $\log \mathrm{P}$ value of 6.35 . High lipophility cause a higher the partition coefficient, but on the other side the higher log $P$ value could reduce the activity (Puspaningtyas et al., 2012).

The increasing of the carbon chain on 2paradol to 6-paradol can affect to decrease the rerank score and increase the lipophility and molar refraction. Otherwise, on 6-paradol to 10 -paradol the value of rerank score increase while the lipophility and the molar refraction have increase. It showed that the affinity of 8paradol and 10-paradol were lower than 6paradol. It may cause of the longer carbon chain induced the lipophility and the molar refraction. If a substance which was too lipophilic and had a big molar refraction would be difficult to pass through the membrane cell. Cell membranes in the body consist of hydrophilic and lipophilic compounds called phospholipid bilayers. If a compound is too hydrophilic or lipophilic, it will be difficult for the compound to enter the cell. Our result showed that 6-paradol had the lowest binding energy, and not significantly with capsaicin as native ligand. This compound also had lipophility value and molar refraction similar to capsaicin.

Other information obtained was the number of carbon chains of 6-paradol and its derivatives. The increase in carbon chains affected their binding to receptor and could be seen through the change in hydrogen bonds and steric interactions. Based on previous research, hydroxyl $(-\mathrm{OH})$ and $-\mathrm{OCH}_{3}$ groups have important functions for the agonist and TRPV1 antagonist compounds (Su et al., 2011). Hydrogen bonds were a strong interaction between hydrogen, which it bound to the atom that had one pair electron with one of oxygen or nitrogen or fluorine. The hydrogen bond of capsaicin, 2-paradol, 4-paradol and 8-paradol were same with leucine and threonine, see at the table 4 and Fig. 2. Otherwise, the 6-paradol had different hydrogen bond, they were glutamine and glutamic acid. Different with the others, 10-paradol did not have any hydrogen bond to receptor. It might cause of the long chain of the structure affect the hydrogen bond. But it did not mean 10-paradol could not bind to the receptor, it bind to the receptor with another interaction. Another interaction that could be observed was steric interaction.

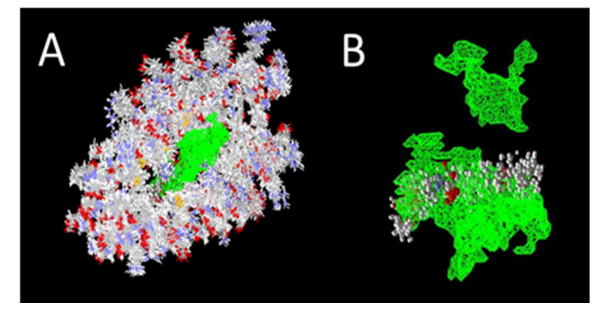

Fig. 1. A. Cavity 1 position in TRPV1 protein (2N27) was shownas the green area, B. The binding site of capsaicin inthe cavity 1

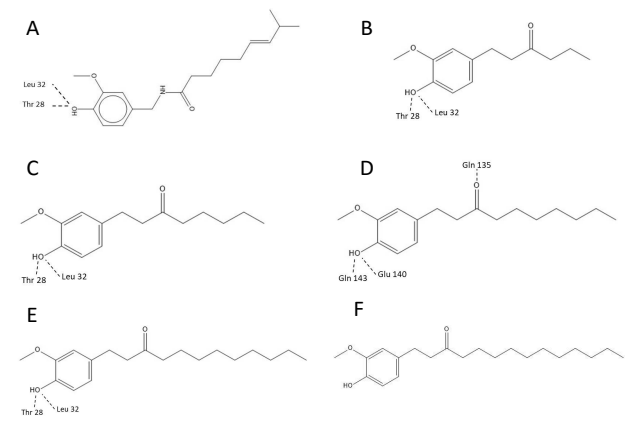

Fig. 2. Hydrogen bonds interaction of A. Capsaicin, B. 2-paradol, C. 4-paradol, D. 6-paradol, E. 8-paradol and F. 10paradol

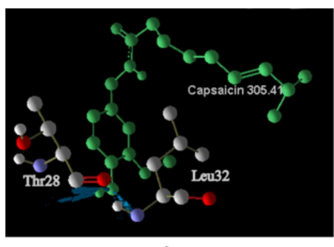

A

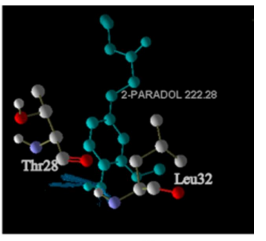

B
Fig. 3. Hydrogen bonds interaction between amino acid and A. Capsaicin, B. 2paradol

Table 4. Hydrogen bonds between amino acid and the compound

\begin{tabular}{cccccc}
\hline \multirow{2}{*}{ Compounds } & Leu 32 & Thr & Glu & Gln & Gln \\
\hline Capsaicin & + & + & - & - & - \\
2-Paradol & + & + & - & - & - \\
4-Paradol & + & + & - & - & - \\
6-Paradol & - & - & + & + & + \\
8-Paradol & + & + & - & - & - \\
10-Paradol & - & - & - & - & - \\
\hline
\end{tabular}


Table 5. Hydrogen bonds Value

\begin{tabular}{cc}
\hline Compounds & $\begin{array}{c}\text { Hbond } \\
\text { value }\end{array}$ \\
\hline Capsaicin & -51.0781 \\
2-Paradol & -52.1486 \\
4-Paradol & -43.4625 \\
6-Paradol & -21.5786 \\
8-Paradol & -21.8456 \\
10-Paradol & 0 \\
\hline
\end{tabular}

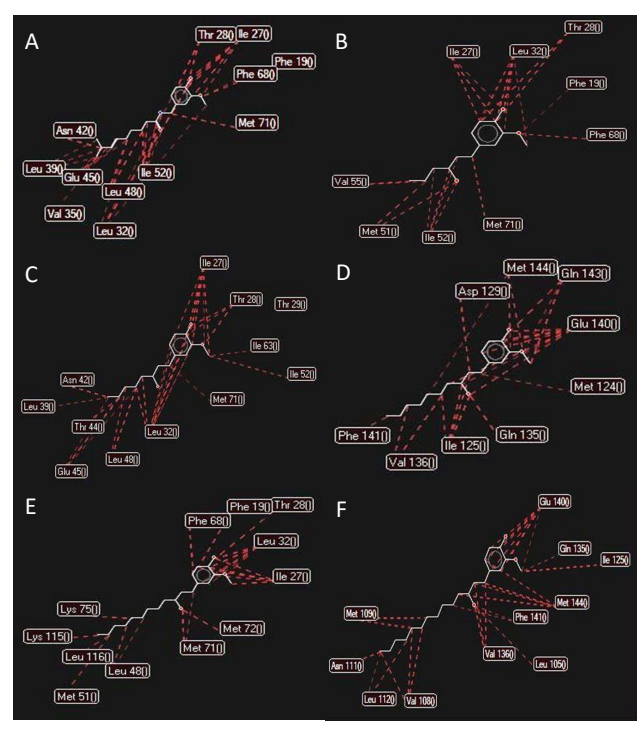

Fig. 4. Steric interactions of A. Capsaicin, B. 2paradol, C. 4-paradol, D. 6-paradol, E. 8-paradol and F. 10-paradol

Steric interactions was related to the clustering properties of the group and the effect of the group compound that bind to the amino acid of the side protein receptor (Suhud, 2015). Steric interactions was related to structure and shape conformation of the compound,in this case was mainly observed the additional of the side chain. Docking compounds were compounds that already had been minimized the energy so that they were expected to be in the most stable conformational form. Steric interactions that occurred in all compounds had different amounts and amino acids and some were the same. As the result capsaicin had steric interaction with threonine, isoleucine, phenylalanine, methionine, leucine, valine, glutamic acid, and asparagine, as we can see in Fig. 3.

When capsaicin is compared with 2-paradol and 4-paradol, it has the same number of steric interactions bondwith some amino acids, they are threonine, methionine, isoleucine, and leucine. Longer chain, especially in 6-paradol, 8-paradol and 10-paradol can affect the number ofsteric interactions which was had additional steric interaction with threonine, isoleucine, phenylalanine, methionine, leucine, valine, glutamic acid, asparagine.

The docking method is carried out in the same position with the native ligan position that has been validated before. However, the conformation structure ofeach compound is differences in the length chain, so it is possible to affect the flexible structure on the part of the chain and also affect to the results in different steric interactions with the receptors. Rigid compounds were usually aromatic compounds.

\section{CONCLUSION}

The smallest rerank score on 6-paradol means ithad the greatest affinity with TRPV1 as same as capsaicin as native ligand (shown in table 2). Further, 6-paradol had the potential to be used as a drug for treating painful diabetic neuropathy.

\section{REFERENCES}

Ali B.H., Blunden G., Tanira M.O., and Nemmar A. 2008. Some phytochemical, pharmacological and toxicological properties of ginger (Zingiber officinale Roscoe): A review of recent research.Food Chem. Toxicol. 46(2): 409-420.

Bhal, S. K. 2019. Application Note Lipophilicity Descriptors: Understanding When to Use Log P \& Log D Application of Lipophilicity Descriptors in Drug. Adv. Chem. Dev. 3-6.

Black C. D., Herring M. P., Hurley D. J., and O'Connor P. J. 2010. Ginger (Zingiber officinale) reduces muscle pain caused by eccentric exercise. J. Pain. 11(9): 894-903.

FajrinF. A., Nugroho A. E., Nurrochmad, A. and Susilowati R. 2018. Molecular docking analysis of ginger active compound on transient receptor potential cation channel subfamily V member 1 (TRPV1). Indones. J. Chem. 18(1): 179-185.

Gaire B.P., Kwon O.W., Park S.H., Chun KH.,Kim S.Y., Shin D.Y., Choi J.W. 2015. Neuroprotective effect of 6-paradol in focal cerebral ischemia involves the attenuation of neuroinflammatory responses in activated microglia. Plos One. 10(3): 1-17.

Gram, Dorte X., Hansen, Anker J., Deacon, 
Carolyn F., Brand, Christian L., Ribel, Ulla, Wilken, Michael, Carr, Richard D., Svendsen, Ove, and Ahrén, Bo. 2005. Sensory nerve desensitization by resiniferatoxin improves glucose tolerance and increases insulin secretion in Zucker Diabetic Fatty rats and is associated with reduced plasma activity of dipeptidyl peptidase IV. Eur. J. Pharmacol. 509(2-3): 211-217.

Haghighi M., Khalvat A., Toliat T., and Jallaei S.2005. Comparing The Effects Of Ginger (Zingiber officinale) Extract And Ibuprofen On Patients With Osteoarthritis. Arch Iran. Med. 8(4): 267-271.

Hutapea F. S., Kembuan, Mieke A. H. N., and P.S., Junita Maja. 2016. Gambaran klinis neuropati pada pasien diabetes melitus di Poliklinik Neurologi RSUP Prof. Dr. R. D. Kandou periode Juli 2014 - Juni 2015.eClinic. 4(1).

Jo, S.K., Kim, I.S., Rehman, S.U., Ha, S.K., Park, H.Y., Park, Y.K., Yoo, H.H. 2016. Characterization of metabolites produced from the biotransformation of 6-shogaol formed by Aspergillus niger.Eur. Food Res. Technol. 242(1): 137-142.

Kano M., Ohno-Shosaku T., Hashimotodani Y., Uchigashima M., and Watanabe M. 2009. Endocannabinoid-mediated control of synaptic transmission.Physiol. Rev. 89(1): 309-380.

Keum, Y.S., Kim, J., Lee, K.H., Park, K.K., Surh, Y.J., Lee, J.M., Lee, S.S., Yoon, J.H., Joo, S.Y., Cha, I.H., Yook, J.I. 2002. Induction of apoptosis and caspase-3 activation by chemopreventive [6]-paradol and structurally related compounds in $\mathrm{KB}$ cells.Cancer Lett. 177(1): 41-47.

Mantiri N.C., Awaloei H., and Posangi J. 2013. Perbandingan Efek Analgesik Perasan Rimpang Jahe Merah (Zingiber officinale var. rubrum Thelaide) Dengan Aspirin Dosis Terapi Pada Mencit (Mus musculus. J. e-Biomedik. 1(1): 518-523.
Nurtjahja-Tjendraputra E., Ammit A. J., Roufogalis B. D., Tran V. H., and Duke C. C. 2003. Effective anti-platelet and COX-1 enzyme inhibitors from pungent constituents of ginger.Thromb. Res. 111(45): 259-265.

Pabbidi R. M., Yu S. Q., Peng S., Khardori R., Pauza M. E., and Premkumar L. S. 2008. Influence of TRPV1 on diabetes-induced alterations in thermal pain sensitivity.Mol. Pain. 4: 1-17.

Puspaningtyas A. R. 2012. Molekular Docking dengan Metode Molegro Virtual Docker Turunan Kalkon sebagai Antimikroba. Stomatognatic (J.K.G Unej). 9(1): 39-47.

Smith H. S. and Argoff C. E. 2013. Pharmacological treatment of neuropathic pain.Pain Int. Res. Pain Manag. 71(5): 203-226.

Su, K., Wook, D., Soo, Y., Seop, M., Park, S., Choi, S., Pearce, L.V. Blumberg, P.M., Lee, J. 2011. Bioorganic \& Medicinal Chemistry Letters Receptor activity and conformational analysis of 50 -halogenated resiniferatoxin analogs as TRPV1 ligands. Bioorg. Med. Chem. Lett. 21(1): 299-302.

Suhud, F. 2015. Uji aktivitas in-silico senyawa baru 1-benzil-3-benzoilurea induk dan tersubstitusi sebagai agen antiproliferatif. Jurnal Farmasi Indonesia. 7(4):242-251.

Suri A. and Szallasi A. 2008. The emerging role of TRPV1 in diabetes and obesity. Trends Pharmacol. Sci. 29(1): 29-36.

Wahyuliati T. 2006. Antidepresan pada nyeri neuropati diabetik. Mutiara Medika. 6(1): 33-41.

Wei, C.K, Tsai, Y.H., Korinek, M., Hung, P.H., El-Shazly, M., Cheng, Y.B., Wu, Y.C., Hsieh, T.J., Chang, F.R.2017. 6Paradol and 6-Shogaol, the Pungent Compounds of Ginger, Promote Glucose Utilization in Adipocytes and Myotubes, and 6-Paradol Reduces Blood Glucose in High-Fat Diet-Fed Mice.Int. J. Mol. Sci. 18(1): 1-18. 